\begin{tabular}{|l|l|l||}
\hline \multicolumn{2}{|c|}{ PublisherInfo } \\
\hline \hline PublisherName & $:$ & BioMed Central \\
\hline \hline PublisherLocation & $:$ & London \\
\hline \hline PublisherImprintName & $:$ & BioMed Central \\
\hline \hline
\end{tabular}

\title{
DNA vaccination against autoimmune disease
}

\begin{tabular}{||l|l|l||}
\hline \multicolumn{2}{|c|}{ ArticleInfo } \\
\hline \hline ArticleID & $:$ & 3775 \\
\hline \hline ArticleDOI & $:$ & $10.1186 /$ gb-spotlight-20000922-01 \\
\hline \hline ArticleCitationID & $:$ & spotlight-20000922-01 \\
\hline \hline ArticleSequenceNumber & $:$ & 212 \\
\hline \hline ArticleCategory & $:$ & Research news \\
\hline \hline ArticleFirstPage & $:$ & 1 \\
\hline \hline ArticleLastPage & $:$ & 2 \\
\hline \hline & & RegistrationDate : 2000-09-22 \\
ArticleHistory & $:$ & OnlineDate $: 2000-09-22$ \\
\hline \hline ArticleCopyright & $:$ & BioMed Central Ltd2000 \\
\hline \hline ArticleGrants & $:$ & \\
\hline \hline ArticleContext & $:$ & 130591111 \\
\hline \hline
\end{tabular}




\section{Jonathan B Weitzman}

Email: JWeitzman@elabseurope.com

Experimental autoimmune encephalomyelitis (EAE) is a T-cell-mediated autoimmune disease of the central nervous system that has been studied as a model for the human disease multiple sclerosis. In the September issue of the Journal of Clinical Investigation Wildbaum et al. (J. Clin. Invest. 2000, 106:671-679) show that injections of naked DNA plasmids, encoding for the Fas ligand (FasL, CD95L) protein, can effectively vaccinate rats against inducible EAE disease. The FasL protein is found on the surface of T-lymphocytes and is critical for regulating the immune response. Wildbaum et al. show that DNA-vaccinated rats produce FasL-specific autoantibodies, which can confer protection to recipient animals if injected at the onset of EAE disease but have a detrimental effect if administered at later stages. Furthermore, these autoantibodies could downregulate TNF $\alpha$ transcription in macrophages. This study offers insights into the use of DNA plasmid therapy for autoimmune diseases.

\section{References}

1. Journal of Clinical Investigation, [http://www.jci.org]

2. The Fas death factor. 